\title{
Social media as a bridge to e-commerce adoption in Indonesia: A research framework for repur- chase intention
}

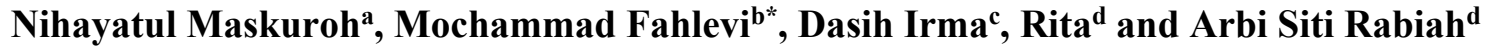

${ }^{a}$ UIN Sultan Maulana Hasanuddin Banten, Indonesia

${ }^{b}$ Management Department, BINUS Online Learning, Bina Nusantara University, Indonesia 11480

${ }^{c}$ Management Department, Kusuma Negara Business School, Indonesia

${ }^{d}$ Global Business Marketing, BINUS Business School, Bina Nusantara University, Indonesia 11480

\section{H R O N I C L E}

\section{Article history:}

Received: June 18, 2021

Received in revised format: July

29, 2021

Accepted: September 28, 2021

Available online: September 28 , 2021

Keywords:

Social Media Marketing

Repurchase Intention

Brand Equity

Customer Relationship

\section{A B S T R A C T}

Consumers today are individuals who fulfill life needs such as shopping using e-commerce. In its fulfillment, consumers can change in terms of purchasing decisions from one e-commerce to another e-commerce. This requires the company to always have a good strategy to compete in a healthy manner in terms of business. To learn about the importance of social media marketing activity, this study will find out how much influence the social media marketing activity received by e-commerce companies has on brand equity, customer relationships and repurchase intention. In addition, the study will learn how much influence brand equity and customer relationship have on an e-commerce company's repurchase intention. In this study, the survey is conducted by distributing questionnaires to respondents online where the research sample has several questions related to the habits and behavior of respondents. This research uses a sample of 210 people who are domiciled in Indonesia. In the research model, the study uses Structural Equation Modeling (SEM) analysis and the software used for this research is IBM SPSS AMOS. The results of the influence of social media marketing activities have the largest positive influence on customer relationships, brand equity is the main and biggest factor that positively and significantly affects repurchase intention in this research model. The accumulated experience and knowledge of consumers about a brand is a factor that can influence consumers to repurchase the same brand. Brand equity not only provides immediate benefits, but also long-term benefits by retaining consumers to continue to repurchase their products. A strong brand will make consumers always remember the brand. The study explains that customer relationships do not have any significant effect on repurchase intention. The main function of customer relationships at first and now is to try to reach their consumers more broadly, especially related to purchases, but this is not proven in repurchases, especially in this study. Customer relationships in the study did not have any significant effect on repurchase intention.

\section{Introduction}

The growth of use through e-commerce certainly has various benefits that are obtained by sellers and consumers by conducting transactions electronically. The benefits that sellers can get in e-commerce are increasing revenue, reducing operating and maintenance costs, reducing purchasing and procurement costs, increasing customer loyalty and retention, reducing transportation costs, developing customer and supplier relationships, increasing sales process speed, improving internal and external

* Corresponding author.

E-mail address: mochammad.fahlevi@binus.ac.id (M. Fahlevi)

(C) 2022 by the authors; licensee Growing Science, Canada. doi: $10.5267 /$ j.ijdns.2021.9.017 
communication and developing company image and brand (Hussain et al., 2020). While the benefits that consumers can get are reducing transaction costs, increasing convenience, saving time, quick and continuous access to information, convenience, being able to switch to another company, being able to buy products that are not available in the local market, being able to comment on product reviews and being able to see what people think. another buy (Prahiawan et al., 2021). Currently, there are many types of e-commerce in Indonesia, including advertising e-commerce, e-commerce market/marketplace, e-commerce shopping mall, social media e-commerce, and e-commerce online shop. e-commerce market/marketplace is one type of e-commerce that has been successfully implemented in Indonesia. e-commerce market/marketplace aims to bridge transactions between sellers and consumers so that the buying and selling process feels safer (Noonan, 2016). Marketplace also provides an opportunity for sellers to advertise their products in the stalls that have been provided. Based on visitor data, 5 ecommerce sites in Indonesia create business competition between platforms. The high competition makes each e-commerce must have the right strategy so that it can continue to be chosen and used by consumers. One way that can be used by ecommerce is to implement good marketing strategies such as advertising on offline and online media to increase the number of application users. One of the marketing strategies used is social media marketing activity (York, 2017). Social media marketing activity is an online marketing strategy that uses the cultural context of social communities including social networks, virtual worlds, social news sites, and social opinion sharing sites for communication (Fahlevi, 2021). Social media marketing activities can be carried out on several social media platforms such as: Instagram, Facebook, Twitter, LinkedIn and Youtube. Social media marketing activity itself has several advantages for companies such as increasing sales, brand value, distributing information about brands and creating customer relationships (Sahir et al., 2021).

In terms of doing shopping activities, consumers will tend to choose brands that are not foreign to them (Al-Debei et al., 2015). Social media marketing is considered more sincere to consumers because it communicates a brand. Repurchase intention is influenced by promotion as stated by Kotler and Armstrong (2018) if one of the promotion objectives is reminding consumers of the company's brand. Many promotions can be done through social media. An important factor in increasing repurchase interest is to make consumers recall a brand or product with the help of promotional media on social media. Using social media marketing activities is expected to help achieve several important company goals such as building brand equity. Brand equity is important for e-commerce to build because a strong brand will help increase sales, increase consumer loyalty, and increase competitive advantage in order to compete with existing competitors (Fang et al., 2016). Social media marketing activity will increase brand equity by interacting, providing and sharing the latest information and providing positive entertainment content. The addition of the company's brand equity will foster value in the minds of the people according to what is perceived, felt, and what is in the public's memory. E-commerce that has strong brand equity will increase the repurchase intention of potential customers. Brand equity itself can be evaluated through brand awareness, brand association, perceived quality, and brand loyalty (Hussain et al., 2020). Consumers today are individuals who fulfill life needs such as shopping using e-commerce. In its fulfillment, consumers can change in terms of purchasing decisions from one e-commerce to another e-commerce. This requires the company to always have a good strategy to compete in a healthy manner in terms of business. Social media marketing activity is also a means to establish customer relationships (Anne-Mette et al., 2013). Customer relationships are very important to be built by companies in order to increase competitive advantages (Kim et al., 2019). With social media marketing activities, companies can easily establish customer relationships by conducting two-way communication with consumers, providing a place for consumers to discuss and receive criticism and reviews from consumers (Ivana et al., 2021). This means of communication will make consumers understand and be aware of the added value of an e-commerce. The process of consumer relations occurs when prospective buyers carry out activities on social media and e-commerce. It is very important for e-commerce to build a positive customer relationship because it can contribute well to customer satisfaction. The success of building customer relationships can be evaluated through trust and intimacy. One of the strategies used to market e-commerce products and services in Indonesia is to use social media marketing activity strategies such as communicating, providing information with consumers, placing advertisements, promotions and collaborating on social media. In Indonesia, the strategy of social media marketing activity is still a hot study that is still widely discussed at the level of marketing application because the application of social media marketing activity can provide very detailed and complex results. Currently, it is important for e-commerce to know the effect of social media marketing activity. This is so that e-commerce can determine the best elements in social media marketing activities according to consumer desires (Liao \& Huang, 2021). Based on Tong (2020) Social media marketing with repurchase intention as a means to provide communication, sales, and relationships between their customers, now social media is considered more sincere to consumers because it communicates a brand. However, according to Karman (2015) research on social media marketing activity still must be done using other dimensions. Not only that, the use of mediation can also be done to see in depth the influence of social media marketing activity on repurchase intention. Brand equity and customer relationships is a mediation that can be used (Hussain et al., 2020). Therefore, seeing the importance of social media marketing activity, this study will find out how much influence the social media marketing activity received by e-commerce companies has on brand equity, customer relationships and repurchase intention. Also, how much influence does brand equity and customer relationship have on an e-commerce company's repurchase intention.

\section{Methodology}

The method used in the data collection process is survey method. The survey method is a method of collecting data using a questionnaire as a research tool, which can be used for both large and small populations, but what is studied is data from samples from that population, so that relationships between variables can be found (Sekaran \& Bougie, 2016). In this study, 
the survey was conducted by distributing questionnaires to respondents online where the research sample would be given several questions related to the habits and behavior of respondents. The sample is part or part of the population there are two types of sampling, namely non-probability sampling and probability sampling. In this study, the researcher uses nonprobability sampling, which is a sampling technique in which the sample unit is selected based on personal considerations or the convenience of the researcher (Saunders et al., 2009). Non-probability sampling is divided into several types of techniques, namely convenience sampling, judgment sampling, quota sampling, and snowball sampling. For this study, the researcher decided to use judgment sampling. Judgment sampling is a non-probability sampling technique in which the researcher selects a sample based on personal considerations regarding some suitable characteristics of the sample members (Lind et al., 2018). Researchers use judgment sampling because this study aims to examine the behavior of responses to social media marketing activities on social media so that researchers choose respondents who have certain characteristics, namely social media users, domiciled in Indonesia and have made purchases in e-commerce within three months. the last and become a follower/follower of the relevant e-commerce social media. In this study, the authors used a sample because the researcher could not reach the entire population of all social media users in Indonesia. According to Hair et al. (2017), to determine the sample size of a population that cannot be calculated are as follows ranged from 5 to 10 times the number of variable questions. From the theory above, the number of indicator items is 42 , so this study uses a minimum of 210 samples. If it is associated with research, it will enter the business survey point, where a sample of around 210 is considered adequate, so for time efficiency and data processing to produce accurate results, the researcher uses a sample of 210 people who are domiciled in Indonesia.

\section{Results and discussion}

In the research model that has been described previously, this study uses Structural Equation Modeling (SEM) analysis and the software used for this research is IBM SPSS AMOS (Hair et al., 2014). The theoretical model that has been described in the path diagram will be analyzed based on the data obtained. Structural model is the relationship between latent variables. Latent variables are variables that cannot be measured directly and require several indicator variables for confirmatory factor analysis. In an SEM Model, a latent variable can function as an independent or dependent variable (Byrne, 2012). The measurement model shows how the manifest variable (indicator) represents the latent variable to be measured, namely by testing the validity and reliability of the latent variable through confirmatory factor analysis.

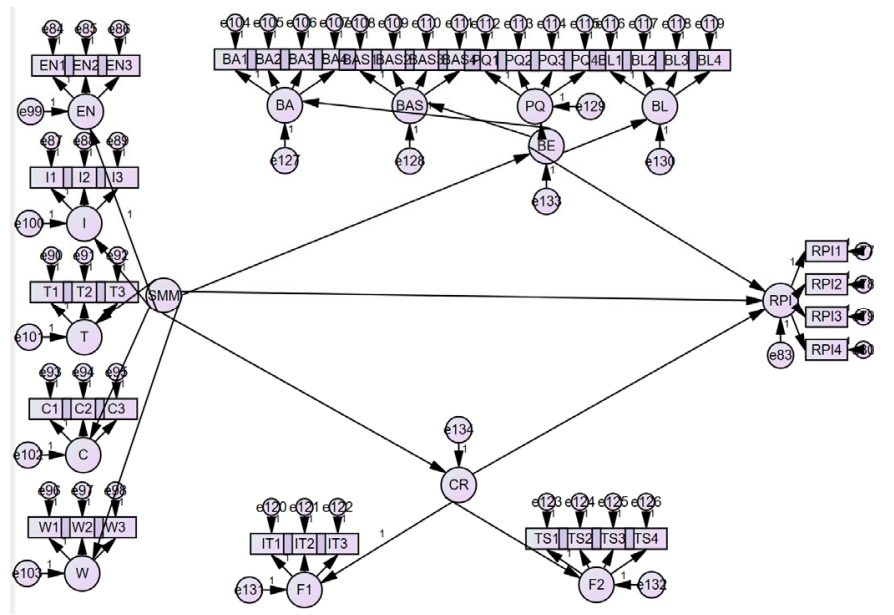

Fig. 1. Full Model

In the model image above, it is known that there is a model using several constructs, namely SMM as an exogenous construct and BE, CR, and RPI as endogenous constructs. This research model uses a second order model so that this study tries to carry out an in-depth analysis to the level of the dimensions of a variable (Kline, 1998), however, the RPI construct is the only variable that does not use the second order because this variable is a pure endogenous construct that is analyzed by factor explaining the variable, so it can be measured directly using indicator items without a second order (dimension). Goodness of fit index (GFI) is a measure of the fit between the hypothesized model and the observed covariance matrix. Adjusted goodness of fit index (AGFI) corrects GFI which is influenced by the number of indicators of each latent variable. GFI and AGFI range between 0 and 1, with values greater than 0.9 generally indicating an acceptable model fit. The relative fit index (also called the "incremental fit index" and "comparative fit index" compares the chi-squared for the hypothesized model with the base model (Byrne, 2012). This null model almost always contains a model in which all variables are uncorrelated, and as a result, has a very large chi-square (indicating a poor fit). The relative fit index includes the normed fit index and the comparative fit index. The comparative fit index (CFI) analyzes the fit of the model by examining the discrepancy between the data and the hypothesized model, while adjusting for sample size problems inherent in the chi-square test of model fit. CFI values range from 0 to 1, with larger values indicating better fit (Hair et al., 2014). Previously, a CFI value of 0.90 or greater was considered to indicate an acceptable model fit. However, recent studies have shown that a value greater than 0.90 is required to ensure 
that a mis specified model is not considered acceptable (Kline, 1998). Thus, a CFI value of 0.95 or higher is currently accepted as a good match indicator (Byrne, 2012). In the picture below, the model test is carried out as follows:

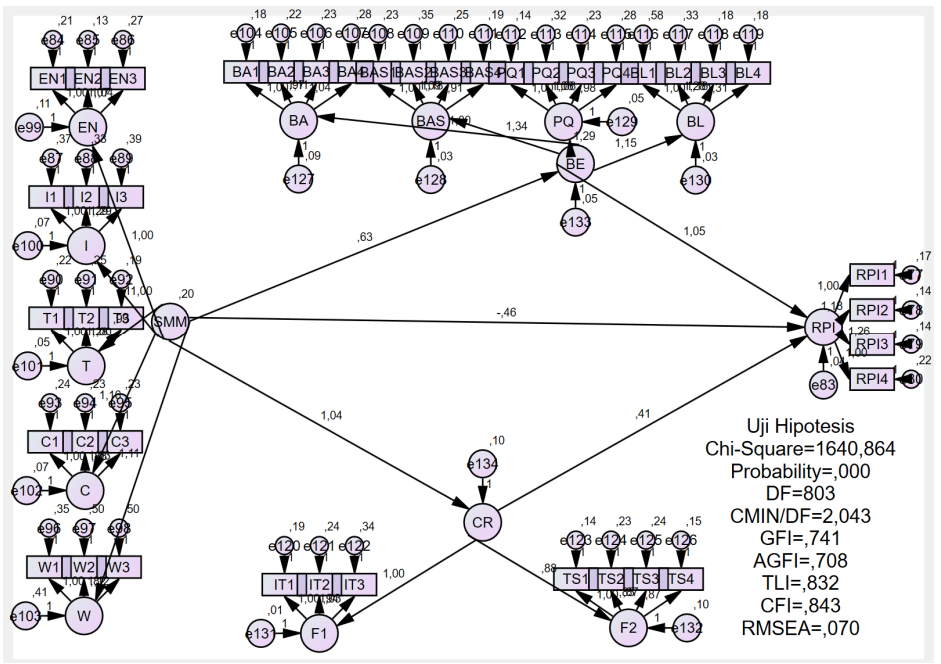

Fig. 2. Goodness of Fit Test

Based on the results of the model test above, it is known that there are still some shortcomings related to the measurement of the feasibility test of the model in this study. This can be seen from several measurement indices that can measure the model made. The results above are compared with the critical values that have been formulated previously to determine whether they are good enough or not.

Table 1

Standardized Direct Effects

\begin{tabular}{|c|c|c|c|}
\hline Variables & Brand Equity & Customer Relationship & Repurchase Intention \\
\hline Social Media Marketing & 0.698 & 0.711 & -0.279 \\
\hline Brand Equity & & & 0.936 \\
\hline Customer Relationship & & & 0.161 \\
\hline
\end{tabular}

The goodness of fit criteria for the estimated structural model can be met, then the next step is an analysis of the Structural Model relationship as shown in the table below. The relationship between constructs in the hypothesis is shown by the value of regression weights (Hair et al., 2014).

Table 2

Regression Weights

\begin{tabular}{|c|c|c|c|c|c|c|c|}
\hline & & & Estimate & S.E. & C.R. & $\mathbf{P}$ & Label \\
\hline BE & $\leftarrow$ & SMM & .575 & .088 & 6.504 & $* * *$ & par_5 \\
\hline CR & $\leftarrow$ & SMM & .931 & .117 & 7.963 & $* * *$ & par_6 \\
\hline RPI & $\leftarrow$ & SMM & -.318 & .100 & -3.175 & .001 & par_3 \\
\hline RPI & $\leftarrow$ & BE & 1.300 & .216 & 6.012 & $* * *$ & par_4 \\
\hline RPI & $\leftarrow$ & CR & .141 & .117 & 1.201 & .230 & par_7 \\
\hline
\end{tabular}

From the researcher's point of view and based on research results that show a strong relationship between social media marketing and brand equity. The positive result from the point of view of this researcher could be due to the increasing number of users of social media marketing and the increasing awareness of its use, so that companies do marketing through social media and take their customers to the company's brand seriously, which will bring the company's brand equity in a better direction. Based on the characteristics of the respondents being young and starting to enter the world of work so that most respondents have financial capabilities independently. Brand preference, especially most respondents living in Jakarta, is very high, social media is one of the best communication tools for companies to be able to communicate and strengthen their brand to respondents who have this background. This research is dominated by the generation called digital native, often their communication in the digital world such as social media is more than the original world. The capital city of Jakarta is the economic center and the city with the highest income level in Indonesia, it would be appropriate if the company did marketing through social media because at this time several features on social media can set specific audiences such as location, age, and gender according to the target of their company. This phenomenon makes digital marketing more effective in reaching consumers in this generation. Social media marketing has the power to be the most attractive asset a business has, helping to enhance customer relationships and drive stronger brand equity. The widespread adoption of social media by consumers and brands 
has drastically changed the relationship between brands and audiences. The presence of a brand online on social media can be an asset that builds brand equity and adds value to consumers and companies (Hussain et al., 2020). Another important research topic is that brand equity is seen as the basis for a new strategic framework to build a more robust and customercentric marketing program that is financially accountable and measurable. Brand equity is an important discussion considering that it can be the basis for formulating a company's strategy, especially in the realm of social media (Cheung et al., 2020).

Customer-based Brand Equity (CBBE) is indicated by an increase in the strength of attitudes, where attitudes can refer to object associations and object evaluations in consumer memory (Akrout \& Diallo, 2017). As explained in the earlier chapter that marketing activities can increase consumer attitudes towards associations and object evaluations, therefore Yoo et al. (2018) state brand equity as "the difference in consumer choice between the focus of branded products and unbranded products given the level of features. the same product." Therefore, an action to show brand equity can be done by comparing two products that are each identical except for the name through an assessment of the intention to buy or preference for the brand. Many companies have taken advantage of social media for marketing and advertising. The use of social media marketing itself has created more possible business opportunities so that customers are now exposed to brand messages by building more interactions (Kim \& Ko, 2012). Brand messages or information conveyed through social media can affect customer perceptions of brand equity. Through marketing activities, the company seeks to create a positive brand evaluation by developing an accessible brand attitude and a consistent brand image to create a maximum impact on purchasing behavior. Therefore, the perceived brand equity will contribute to influencing purchase intention in the future. Social media marketing activities are a key factor in consumer relations: Customers conduct research on products or services they are willing to buy, through social media. To expand communication with clients, companies use social media and the result is: better customer interaction. Customer relationship discusses how to get closer to consumers, especially regarding communication with consumers (Liu et al., 2011). Based on the characteristics of respondents who are young and dominated by female respondents where they usually look for references about a product they are comparing on social media, therefore social media marketing is very important for this group, e-commerce competition in Indonesia is quite tight so companies try to retain their customers and attract potential customers. The results of the influence of social media marketing activities are the biggest influence on customer relationships, this is because social media is the most appropriate tool at this time in establishing relationships between companies and their consumers, not infrequently we see e-commerce companies using several endorsements made by celebrity to improve their relationship with their potential customers or potential customers.

These results are in accordance with research conducted by Kim and Ko (2012) that social media marketing activities carried out by a brand affect the customer relationship of the brand. This result is also supported by research by Taylor and Hunter (2002) which explains that by increasing customer relationships, the relationship between consumers and brands will be stronger. In the era of increasingly advanced technology, communication is mostly on social media. Social media is actually an open communication about satisfaction and dissatisfaction, likes and dislikes. Getting closer to consumers means companies must adapt to the rise of social media in order to remain competitive in the market. This is the reason why organizations must use social media in marketing and they must accept this transition from traditional customer relationships (email, telephone, brochures) to a new model of customer relationship. We call it transition because companies should not forget old customer relationship practices but integrate new ones and focus their attention on them. Most companies use social media to communicate with customers and respond to their questions and complaints, while more than half use social media to increase sales: generate sales leads and sell products. The survey in this study also revealed that more than $50 \%$ of e-commerce companies use social media to promote their platforms. Companies also use social media for consumer reviews, in providing support or finding out consumer ideas. They use social media as a marketing tool for more than just collecting and analyzing data. When a company does marketing through social media, it has no control over what its followers or consumers do. Multiple users interact with each post, and they are free to spread the message among their friends. While this can benefit the company, it can also backfire when a post gives a negative impression about the company. Interactions like retweets, comments, likes, and shares can get a post popular within minutes. Marketing through social media is indeed effective in several studies, especially related to purchase intention, but the results of this study prove that it has a negative effect on repurchase intention, so it can be concluded that social media marketing carried out by e-commerce is only effective for customers. potential is not for existing consumers. Some studies explain that it is more difficult to retain existing customers than to find new potential customers (Zheng et al., 2017). Based on the characteristics of the respondents in this study, it is known that the majority of respondents use Shopee's e-commerce when compared to other e-commerce. Shopee is one of the companies that do fewer social media marketing activities compared to Tokopedia and Bukalapak. Shopee focuses its business on pricing strategies and coupons and free shipping which are more attractive for consumers to repurchase, especially for the younger generation who are also most respondents in the study aged 18-25 years who are college age and fresh graduates. The results of this study have a unidirectional or negative effect and contradict the previous research conducted by Herlyana and Utami (2020) that Social Media Marketing Activities are said to be able to affect consumers repurchase intentions and Nunes et al. (2018) also found that the increasing use of social media marketing makes the increase in repurchase intentions due to feedback or reviews given to a product through the social media marketing. Freberg et al. (2011) states that social media is a good marketing tool to increase consumer repurchase intention. Not all reviews or those discussed on social media about e-commerce companies are good, there are also bad reviews that can affect consumers in repurchase intention.

The company's followers will be able to view the content just like any other potential customer who has interacted with the company. After a while, the company begins to feel powerless because the company cannot control what is said about the 
company. Trying to tell the story from the company side doesn't always result in a positive response. No one can deny that social media is a very effective tool to increase engagement and increase sales. However, companies should not think of it as the only marketing avenue to pursue. Being dependent on certain social media platforms makes companies vulnerable to future changes that may be made to the way these communications are made. The company should explore different marketing options and then determine the appropriate combination for the company's services and products. Diversification of a company's marketing efforts is necessary if a company is to gain the positive effects of social networking. However, most companies end up prioritizing social media too much. From the results above, we can see that social media marketing is not enough to increase repurchase intention, there must be media variables such as brand equity so that the influence of social media marketing becomes positive and significant. Brand equity is known to have a central role in marketing on social media, so marketing on social media can have a positive impact on the company, one of which has a positive impact on repurchase intention. In the results of this study, it is known that brand equity is the main and biggest factor that affects repurchase intention in this research model. The initial stage needed to build a brand is how manufacturers build Brand Awareness through information in memory. Brand awareness is important before brand associations and brand equity can be formed. When consumers have little time to consume, proximity to the brand name will be enough to determine the purchase. The concept of brand equity is the ability of buyers to identify (recognize or remember) a brand that is detailed enough to make a purchase. Brand equity is the first step for every consumer of any new product or brand offered through advertising. Based on the identity of the respondents in this study, it is known that most of them consist of women who have high brand preference characteristics in several studies (Hussain et al., 2020). Brand equity is the most important thing in determining whether a consumer buys back or not, especially in online purchases provided by e-commerce. The accumulated experience and knowledge of consumers about a brand is a factor that can influence consumers to repurchase the same brand. Brand equity not only provides immediate benefits, but also long-term benefits by retaining consumers to continue to repurchase their products. A strong brand will make consumers always remember the brand. Based on the CBBE model in building towards high brand equity only occurs in consumers who are aware of the existence of a brand and have a strong, profitable image/association, and are aware of the uniqueness or advantages of a particular brand. (Keller et al., 2011) suggests the process of steps in building a brand, formulating the right brand identity, creating the meaning of the brand in accordance with the formulation, stimulating the expected brand response, establishing the right brand relationship with consumers. The overall result will have an impact on the company because the credibility of the brand and the credibility of the company are closely related.

Repurchase intention is an interesting discussion today when all transactions can be done online. Many players in the ecommerce industry make every company try to retain their customers where these consumers can also become consumers of competing companies in the same industry. Digital transactions have made a shift regarding repurchase because consumers can switch places (platforms) in just seconds, unlike traditional transactions. The results of this study explain that customer relationships do not have a significant effect on repurchase intention. Based on the respondent's data, this study found that respondents are indeed active in social media and have more than 1 e-commerce application. Experience and brand equity are still the main considerations in repurchase intention. In this study, it is known that most of the respondents are young and in several surveys that young consumers have less interest in companies that massively advertise on social media, because they perceive advertising as a distraction when they use social media (Ishadi \& Indi Djastuti, 2012). The main function of customer relationships at first and now is to try to reach their consumers more broadly, especially related to purchases, but this is not proven in repurchases, especially in this study. The results of this study are not in accordance with previous research conducted by Kim and Ko (2010) that Customer Relationship affects Purchase Intention. Especially the research conducted by Taylor and Hunter (2002) which says the use of social media to maintain customer relationships will increase repurchase intention from customers. Customer relationships in the study did not find that it did not have a significant effect on repurchase intention.

\section{Conclusion}

E-commerce now plays an important role in our daily life. It is redefining commercial activity worldwide. Over the years, ecommerce has developed rapidly into a new lifestyle in online shopping. This study has attempted to formulate the important factors in repurchasing in the e-commerce industry in Indonesia by using 3 variables, namely social media marketing activities, brand equity, and consumer relations. The results of this study have indicated a strong and significant positive relationship between social media marketing activities and brand equity. The positive result from the point of view of this researcher could be due to the increasing number of users of social media marketing and the increasing awareness of its use, so that companies do marketing through social media and take their customers to the company's brand seriously, which will bring the company's brand equity in a better direction. The results of the influence of social media marketing activities are the largest positive influence on customer relationships and this is significant because social media is the most appropriate tool today in establishing relationships between companies and their consumers, it is not uncommon to see e-commerce companies using several endorsements by celebrities to improve their relationship with their potential customers or potential customers. In the results of this study, it is known that brand equity is the main and biggest factor that positively and significantly affects repurchase intention in this research model. The accumulated experience and knowledge of consumers about a brand is a factor that can influence consumers to repurchase the same brand. Brand equity not only provides immediate benefits, but also long-term benefits by retaining consumers to continue to repurchase their products. A strong brand will make consumers always remember the brand. The results of this study explain that customer relationships do not have a significant effect on repurchase 
intention. The main function of customer relationships at first and now is to try to reach their consumers more broadly, especially related to purchases, but this is not proven in repurchases, especially in this study. Customer relationships in the study did not find that it did not have a significant effect on repurchase intention.

\section{References}

Akrout, H., \& Diallo, M. F. (2017). Fundamental transformations of trust and its drivers: A multi-stage approach of businessto-business relationships. Industrial Marketing Management, 66, 159-171.

Al-Debei, M. M., Akroush, M. N., \& Ashouri, M. I. (2015). Consumer attitudes towards online shopping: The effects of trust, perceived benefits, and perceived web quality. Internet Research, 25(5), 707-733. https://doi.org/10.1108/IntR-05-20140146

Anne-Mette, S., Ragnhild, N. E., \& H., O. A. (2013). Employer branding: Employer attractiveness and the use of social media. Journal of Product \& Brand Management, 22(7), 473-483. https://doi.org/10.1108/JPBM-09-2013-0393

Byrne, B. M. (2012). Choosing structural equation modeling computer software: Snapshots of LISREL, EQS, AMOS, and Mplus. In Handbook of structural equation modeling. (pp. 307-324). The Guilford Press.

Cheung, M. L., Pires, G., \& Rosenberger, P. J. (2020). The influence of perceived social media marketing elements on consumer-brand engagement and brand knowledge. Asia Pacific Journal of Marketing and Logistics.

Fahlevi, M. (2021, April). Online consumer behaviour and its relationship to website atmospheric induced flow: Insights into online travel agencies in Indonesia. In IOP Conference Series: Earth and Environmental Science (Vol. 729, No. 1, p. 012114). IOP Publishing.

Fang, J., Wen, C., George, B., \& Prybutok, V. R. (2016). Consumer heterogeneity, perceived value, and repurchase decisionmaking in online shopping: The role of gender, age, and shopping motives. Journal of Electronic Commerce Research, 17(2), 116-116.

Freberg, K., Graham, K., McGaughey, K., \& Freberg, L. A. (2011). Who are the social media influencers? A study of public perceptions of personality. Public Relations Review, 37(1), 90-92.

Hair, J. F., Gabriel, M., \& Patel, V. (2014). AMOS Covariance-Based Structural Equation Modeling (CB-SEM): Guidelines on Its Application as a Marketing Research Tool by Joseph F. Hair, Marcelo Gabriel, Vijay Patel: SSRN. Brazilian Journal of Marketing, 13(2).

Hair, J. F., Hult, G. T. M., Ringle, C. M., \& Sarstedt, M. (2017). A Primer on Partial Least Squares Structural Equation Modeling (PLS-SEM) (2nd ed.). Sage.

Herlyana, F., \& Utami, L. S. S. (2020). Pengaruh Daya Tarik Iklan di Konvergensi Media Terhadap Brand Awareness (Studi Iklan Tiket. Com di YouTube Pada Kalangan Generasi Z di Jakarta). Prologia, 4(1), 160-166.

Hussain, S., Melewar, T. C., Priporas, C. V., Foroudi, P., \& Dennis, C. (2020). Examining the effects of celebrity trust on advertising credibility, brand credibility and corporate credibility. Journal of Business Research, 109(November 2019), 472-488. https://doi.org/10.1016/j.jbusres.2019.11.079

Ishadi \& Indi Djastuti. (2012). Analisis Pengaruh Ketidakpuasan Konsumen, Iklan Pesaing Dan Perilaku Mencari Variasi Terhadap Perilaku Perpindahan Merek Pada Konsumen Shampo Sunsilk. Diponegoro Journal of Management.

Ivana, M. T., Ambarita, R. J., Fahlevi, M., Prabowo, H., \& Ngatindriatun, N. (2021). Effect of Website Quality on Customer Satisfaction and Purchase Intention at PT. Susan Photo Album. 1, 568-573.

Keller, K. L., Parameswaran, M. G., \& Jacob, I. (2011). Strategic brand management: Building, measuring, and managing brand equity. Pearson Education India.

Kim, A. J., \& Ko, E. (2012). Do social media marketing activities enhance customer equity? An empirical study of luxury fashion brand. Journal of Business Research, 65(10), 1480-1486.

Kim, W.-H., Cho, J.-L., \& Kim, K.-S. (2019). The relationships of wine promotion, customer satisfaction, and behavioral intention: The moderating roles of customers' gender and age. Journal of Hospitality and Tourism Management, 39, 212218.

Kline, R. B. (1998). Software Review: Software Programs for Structural Equation Modeling: Amos, EQS, and LISREL. Journal of Psychoeducational Assessment, 16(4), 343-364. https://doi.org/10.1177/073428299801600407

Kotler, P., \& Armstrong, G. (2018). Principles of Marketing 17th Global Edition.

Liao, L., \& Huang, T. (2021). The effect of different social media marketing channels and events on movie box office: An elaboration likelihood model perspective. Information \& Management, 58(7), 103481.

Lind, D. A., Marchal, W. G., \& Wathen, S. A. (2018). Statistical Techniques in Business \& Economics (17th ed., p. 897). McGraw Hill Education.

Liu, C. T., Guo, Y. M., \& Lee, C. H. (2011). The effects of relationship quality and switching barriers on customer loyalty. International Journal of Information Management. https://doi.org/10.1016/j.ijinfomgt.2010.05.008

Noonan, J. (2016). Leadership in the Hotel Industry What it takes to be a CEO in today's global marketplace. SpencerStuart.

Nunes, R. H., Ferreira, J. B., de Freitas, A. S., \& Ramos, F. L. (2018). The effects of social media opinion leaders' recommendations on followers' intention to buy. Revista Brasileira de Gestão de Negócios, 20(1), 57-73.

Prahiawan, W., Fahlevi, M., Juliana, J., Purba, J., \& Tarigan, S. (2021). The role of e-satisfaction, e-word of mouth and etrust on repurchase intention of online shop. International Journal of Data and Network Science, 5(4), 593-600.

Sahir, S. H., Sugito, S., Hasibuan, A., \& Fahlevi, M. (2021). Customer Experience Management: The Online Travel Agencies in Indonesia. ICIC Express Letters Part B: Applications, 12(4), 369-375. 
Saunders, M., Lewis, P., \& Thornhill, A. (2009). Research Methods for Business Students (5th ed.). Prentice Hall. Sekaran, U., \& Bougie, R. (2016). Research methods for business: A skill building approach. John Wiley \& Sons.

Taylor, S. A., \& Hunter, G. L. (2002). The impact of loyalty with e-CRM software and e-services. International Journal of Service Industry Management.

Tong, T. K. P. B. (2020). Analisa pengaruh social media marketing terhadap repurchase intention melalui brand trust sebagai variabel mediasi pada instagram adidas Indonesia di Surabaya. Jurnal Strategi Pemasaran, 7(1), 10.

Yoo, J., Lee, H., \& Jin, Y. (2018). Effects of Celebrity Credibility on Country's Reputation: A Comparison of an Olympic Star and a Political Leader. Corporate Reputation Review, 21(3), 127-136. https://doi.org/10.1057/s41299-018-0048-5

York, A. (2017). Social Media Demographics for Marketers | Sprout Social. Sproutsocial.

Zheng, X., Lee, M., \& Cheung, C. M. K. (2017). Examining e-loyalty towards online shopping platforms: The role of coupon proneness and value consciousness. Internet Research. https://doi.org/10.1108/IntR-01-2016-0002

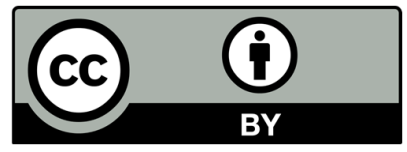

(C) 2022 by the authors; licensee Growing Science, Canada. This is an open access article distributed under the terms and conditions of the Creative Commons Attribution (CC-BY) license (http://creativecommons.org/licenses/by/4.0/). 